\title{
INFLUENCING FACTORS OF COLLEGE STUDENTS' \\ PHYSICAL HEALTH UNDER THE INTERVENTION OF FOOTBALL
}

\author{
FATORES DE INFLUÊNCIA DA SAÚDE FISICA DE ESTUDANTES UNIVERSITÁRIOS SOB A INTERVENÇÃO \\ DOFUTEBOL
}

\author{
ANÁLISIS DE LOS FACTORES QUE INFLUYEN EN LA SALUD FISICA DE LOS ESTUDIANTES UNIVERSITARIOS \\ BAJO LA INTERVENCIÓN DEL FÚTBOL
}

\section{Jin Gang' (ID \\ (Sports Sociology)}

1. Physical Education Department, Northeastern University, Shenyang, Liaoning, 110000, China.

\section{Correspondence:}

Shenyang, Liaoning, 110000, China. gwljv2591064@163.com

\begin{abstract}
The current football can effectively exercise the body of college students and improve their physical health. How to use modern intelligent technology to perform quantitative research on the influencing factors of football on college students' physical health is the current development trend. Based on this, this paper studies the influencing factors of college students' physical health under the intervention of football. First of all, this paper puts forward an analysis model of college students' physical health based on the sarsa algorithm. The autocorrelation function is used to simulate and process the students' physical information. Through the maximum value of the autocorrelation function curve in the detection process, the detection signal is restored, then the error of the sarsa algorithm is analyzed. Secondly, this paper expounds the influence factors of sarsa algorithm on students' physical health in football. Fuzzy evaluation method and analytic hierarchy process are used in the evaluation. Aiming at the shortcomings of AHP, the improved sarsa algorithm is used for comprehensive analysis, and an adaptive simulation evaluation system is established. Finally, the effectiveness of the sarsa algorithm in this system is verified by many football experiments.
\end{abstract}

Keywords: Football, physical health; sarsa algorithm; analytic hierarchy process.

\section{RESUMO}

O futebol atual pode efetivamente exercitar o corpo de estudantes universitários e melhorar sua saúde física. Como usar a tecnologia moderna inteligente para realizar pesquisas quantitativas sobre os fatores que influenciam o futebol na saúde física dos estudantes universitários é a tendência de desenvolvimento atual. Com base nisso, este documento estuda os fatores que influenciam a saúde física dos estudantes universitários sob a intervenção do futebol. Em primeiro lugar, este artigo apresenta um modelo de análise da saúde física dos estudantes universitários com base no algoritmo sarsa. A função de autocorrelação é usada para simular e processar as informações físicas dos alunos. Através do valor máximo da Curva da função de autocorrelação no processo de detecção, o sinal de detecção é restaurado, e então o erro do algoritmo de sarsa é analisado. Em segundo lugar, este documento expõe os fatores de influência do algoritmo sarsa sobre a saúde física dos estudantes no futebol. O método de avaliação aproximado e o processo hierárquico analítico são utilizados na avaliação. Visando as deficiências do AHP, o algoritmo de sarsa melhorado é usado para uma análise abrangente, e um sistema de avaliação de simulação adaptável é estabelecido. Finalmente, a eficácia do algoritmo sarsa neste sistema é verificada por diversos experimentos com futebol.

Descritores: Futebol, saúde física; algoritmo de sarsa; processo de hierarquia analítica.

\section{RESUMEN}

El fútbol actual puede ejercitar eficazmente el cuerpo de los universitarios y mejorar su salud física. La tendencia de desarrollo actual es como utilizar la moderna tecnología inteligente para realizar investigaciones cuantitativas sobre los factores del fútbol que influyen sobre la salud física de los estudiantes universitarios. Con base en esto, este trabajo estudia los factores que influyen en la salud física de los estudiantes universitarios por la intervención del fútbol. En primer lugar, este artículo presenta un modelo de análisis de la salud física de los estudiantes universitarios basado en el algoritmo sarsa. La función de autocorrelación se utiliza para simular y procesar la información física de los estudiantes. Por medio del valor máximo de la curva de la función de autocorrelación en el proceso de detección, se restaura la señal de detección, luego se analiza el error del algoritmo sarsa. En segundo lugar, este artículo expone los factores de influencia del algoritmo sarsa en la salud física de los estudiantes en el fútbol. En la evaluación se utilizan el método de evaluación difusa y el proceso de jerarquía analítica. Apuntando a las deficiencias de PJA, el algoritmo mejorado de sarsa se utiliza para un análisis integral y se establece un sistema de evaluación de simulación adaptativa. Finalmente, la efectividad del algoritmo sarsa en este sistema es verificada por muchos experimentos de fútbol.

Descriptores: Fútbol, salud; algoritmo de salsa; análisis estratificado 


\section{INTRODUCTION}

The research on human physical health in China has been carried out for a long time, and there are many contents involved. From the perspective of simulation of human physical health, it is analyzed, including local joint simulation, signal simulation and visual simulation. In addition, in the process of zhozi's research on the influence of sports on human health, football is also a hot spot. From the perspective of football, in addition to the passing of football, it also involves the part of shooting skills, which has been widely concerned at home and abroad since the 1930s. The core content of the impact of football on human health is to evaluate the efficiency of team cooperation, which is of great value to the research on promoting human body fat loss and muscle gain.' In the 1980s, the quantitative analysis methods began to appear in the research of football simulation, and the quantitative analysis methods increased continuously. Since then, the theory of the influence of football on human health began to pursue diversified balance. In foreign research theory, the evaluation of simulation part of football is considered to be the most important part. We hope to improve the athletes' physique by this way, and also achieved good results. The domestic Institute of human physical health has also carried out the reform of football intervention, and various simulation models have been emerging. Such as analytic hierarchy process. In this context, this paper proposes an analysis model of the influence factors of football on College Students' physical health based on the improved sarsa algorithm.

The innovation of this paper is to put forward a simulation system of football energy consumption on human body based on the improved sarsa algorithm. On this basis, the system can not only realize the daily recording and storage of different football sports' time length information data, but also make full use of the position difference between each human body's physical health, and realize the human body through data comparison and analysis The closed-loop evaluation of physical health in the process of football. On the other hand, the ACF difference factor is used to quantitatively describe the data matching degree between the comparison column and the reference column and the difference amount of the standard data. ${ }^{2}$ The priority of the football simulation standard is completed by the quantitative index, which can effectively analyze and extract the characteristics of the factors affecting human physical health. ${ }^{3}$

This paper studies the evaluation system of College Students' physical health based on sarsa algorithm, which is mainly divided into three parts. The first part introduces the research status of football on human health at home and abroad. In the second part, the human health evaluation model based on the sarsa algorithm is constructed. The improved sarsa algorithm in time domain is used to construct the inner product calculation model of the simulation data vector and the evaluation index system affecting the simulation quality. The third part of this paper constructs the football intervention under the impact of College Students' physical health simulation system for practical testing, analysis of the results, draw a conclusion.

At present, at home and abroad, there is a problem of low intelligence in the study of football influencing factors on human health, so many experts and scholars have studied the technology of football simulation. According to the position differences of different human bodies in football matches, scholars from Berlin University of Germany put forward targeted improvement strategies for the growth of muscle content in human physical health. ${ }^{4}$ Based on the improvement of the information input mode of football consumption model, scholars from National University of Singapore proposed a human health impact assessment model based on neural network algorithm. ${ }^{5}$ The data signals input to the model were collected by nodes in a normalized way, and the information simulation processing of data signals was realized by neural network algorithm. Scholars from Macao University of science and technology of China found that most colleges and universities still follow the traditional thinking of human body physique research simulation, ignoring the use of intelligent information technology. Therefore, the current football consumption simulation model often uses the freeze frame input characteristics, proposes the method of specific data information clustering analysis and processing, and collects and detects the input information in real time. ${ }^{6}$ According to the science of information technology, scholars from Seoul University of South Korea proposed that we should pay attention to the development and construction of human physical health system based on the limited factors of football intervention, and enhance the management and attention to the data and information of energy consumption in the process of football. In order to improve the efficiency of fat burning between football games, Hong Kong Polytechnic University of China proposed an innovative evaluation method based on neural network algorithm and related theories. Through the research and analysis of human performance and score difference in different football matches, a new "end-to-end" football energy consumption evaluation system was proposed, and the system was verified in practice Effectiveness in football. The results show that the innovative football match system has the advantages of high stability and objective evaluation. ${ }^{8}$

To sum up, it can be seen that most of the current human health impact systems do not involve the human health impact assessment model based on the improved sarsa algorithm. On the other hand, although our country has done a lot of basic research on human physical health, there are relatively few research results in the specific quantitative dynamic evaluation of the impact of football on human health.

\section{The process of determining the evaluation index of the in- fluence of football on College Students' physical health}

In order to study the influence of football on College Students' physical health, the hierarchical relationship of evaluation indexes used in this paper is expressed by set

$$
\left\|U_{i}\right\|_{2}^{2}=\|\left(\frac{\left(U_{i 1}, \cdots, U_{i m}\right)}{m} \|_{2}^{2}(1)\right.
$$

In the evaluation function of College Students' physical health, it is assumed that the weight coefficient of the first level index is expressed by $a_{i}$ and is greater than 0 , and a is used to represent the weight vector of $\mathrm{U}$. Each secondary index also has its own weight coefficient, which is represented by a, and the weight vector is expressed as $A_{i}$, which is also greater than zero. Therefore, this study adopts five levels of classification method, and the simulation evaluation results of different football sports on College Students' physical health influence factors are divided into significant influence and no influence. After determining the classification of grades, the five grades are assigned with 5-point assignment method, with significant impact rating interval [4.5, 5], general impact rating interval $[3.5,4.4]$, basic impact rating interval $[3,3.4]$, not much impact rating interval $[2.5,2.9]$, and no impact on rating interval $[0,2.4]$. The evaluation system of each column is shown in Table 1.

Table 2 is the experimental results of influencing factors of College Students' physical health under the intervention of football. The relevant data in this evaluation model are processed by MATLAB software.

Table 1. Sample matrix.

\begin{tabular}{c|c|c|c|c}
\hline Index & $\mathbf{1}$ & $\mathbf{2}$ & $\ldots$ & $\mathbf{P}$ \\
\hline$U^{11}$ & $d_{111}$ & $d_{112}$ & $\ldots$ & $d_{11 \mathrm{p}}$ \\
\hline$U_{12}$ & $d_{112}$ & $d_{122}$ & $\ldots$ & $d_{12 \mathrm{p}}$ \\
\hline$\ldots$ & $\ldots$ & $\ldots$ & $\ldots$ & $\ldots$ \\
\hline$U_{\mathrm{mn}}$ & $d_{\mathrm{mn} 1}$ & $d_{\mathrm{mn} 2}$ & $\ldots$ & $d_{\mathrm{mnp}}$ \\
\hline
\end{tabular}


Table 2. Weight vector of grey evaluation.

\begin{tabular}{c|c|c|c|c|c|c}
\hline index & $\mathbf{4 . 5}$ & $\mathbf{4 . 5}$ & $\mathbf{5}$ & $\mathbf{5}$ & $\mathbf{4 . 5}$ & weight \\
\hline $\begin{array}{c}\text { Experimental } \\
\text { Group 1 (1h) }\end{array}$ & $f_{1}(4.5)$ & $f_{1}(4.5)$ & $f_{1}(5)$ & $f_{1}(5)$ & $f_{1}(4.5)$ & 0.4389 \\
\hline $\begin{array}{c}\text { Experimental } \\
\text { Group 2 (2h) }\end{array}$ & $f_{2}(4.5)$ & $f_{2}(4.5)$ & $f_{2}(5)$ & $f_{2}(5)$ & $f_{2}(4.5)$ & 0.6970 \\
\hline $\begin{array}{c}\text { Experimental } \\
\text { Group 3 (3h) }\end{array}$ & $f_{3}(4.5)$ & $f_{3}(4.5)$ & $f_{3}(5)$ & $f_{3}(5)$ & $f_{3}(4.5)$ & 0.8313 \\
\hline $\begin{array}{c}\text { Experimental } \\
\text { Group 4 (4h) }\end{array}$ & $f_{4}(4.5)$ & $f_{4}(4.5)$ & $f_{4}(5)$ & $f_{4}(5)$ & $f_{4}(4.5)$ & 0.9928 \\
\hline
\end{tabular}

The evaluation criteria are divided into five grades, with 5 points for significant impact, 4 points for general impact, 3 points for basic impact, 2 points for minor impact and 1 point for no impact. In addition, there are experts to form an evaluation group. According to the evaluation index scoring standard, the energy consumption and muscle stretching effect of different football games are quantitatively scored. Considering that there are 19 three-level indicators, these index data are very large. In order to facilitate calculation, the matrix is divided into blocks in the research and analysis. The grey theory is used to evaluate the first grade index and the top evaluation target. In order to facilitate the calculation, all kinds of indicators are numbered first, and then the weight is calculated.

According to the data in the table, we can get the grey evaluation vector of the index. The same method is used to calculate the grey evaluation vector of other indexes. Finally, the grey evaluation matrix of College Students' physical health evaluation under the intervention of football is obtained, and the weight vector $\mathrm{a}=(0.35,0.35,0.15,0.15)$ can be obtained, and then the comprehensive evaluation weight vector of simulation index of health influencing factors can be obtained: $B=a \cdot r=(0.1630,0.3371,0.1887,0.1899,0.1213)$. Finally, the gray comprehensive evaluation value $\mathrm{W}$ of different experimental groups is calculated, Therefore, $w=B \cdot(5,4,3,2,1) t=4.0602$. Human physical health $w$ belongs to the second grey class with the largest weight, so the evaluation quality is good. If the maximum weight principle is followed, the result error is slightly larger, but it is still within the controllable range. This is because the method of maximum weight principle does not consider the comprehensive elements, resulting in the decline of accuracy.

\section{CONCLUSIONS}

Football has an important impact on College Students' physical health, but there are some problems in the process of College Students' physical health impact evaluation, such as low intelligence, poor unified evaluation effect and so on. Based on this, this paper studies the evaluation system of influencing factors of human physical fitness and health based on the improved sarsa algorithm. Firstly, an architecture model based on the sarsa algorithm is proposed. The autocorrelation function and gray fuzzy evaluation function are used. Firstly, the human body constitution change signals under different football periods are processed, and the detection signal is restored by the maximum value of the autocorrelation function curve in the pitch period. Finally, the error of the improved sarsa algorithm is analyzed. Secondly, the evaluation model of human health factors based on sarsa algorithm is constructed. In the evaluation, fuzzy evaluation method and analytic hierarchy process based on Saras algorithm are used. Then, from the theoretical level, the deficiencies of AHP are improved, and an adaptive simulation quality evaluation system is established. Finally, the effectiveness of the model is verified by an example of football intervention. Experiments show that the model based on the improved sarsa algorithm has the advantages of good reliability, high intelligence and strong resistance to subjective factors, which is suitable for college football and college students' physique detection in multi scenes.

The author declare no potential conflict of interest related to this article

AUTHORS' CONTRIBUTIONS: The author has completed the writing of the article or critical comments on its knowledge content. This paper can be used as the final manuscript. Every author has made an important contribution to this manuscript. Jin Gang: write and execute.

\section{REFERENCES}

1. Cvetkovi N, Stojanovi E, Stojiljkovi N, D Nikolić, A T Scanlan, Z Milanović. Exercise training in overweight and obese children: Recreational football and high-intensity interval training provide similar benefits to physical fitness. Scandinavian Journal of Medicine \& Science in Sports. 2018; 28(Supplement 1):18-32.

2. Fung E, Lui L, Yau F, J Leung, J Woo. Performance of cardiopulmonary exercise capacity and physical fitness indicators in differentiating pre-frail and robust elderly. Canadian Journal of Cardiology. 2018; 34(10):S6-S7

3.

4. Muscella $A$, Vetrugno $C$, Spedicato $M$, Stefàno $E$, Marsigliante $S$. The effects of training on hormonal concentrations in young soccer players. Journal of Cellular Physiology. 2019; 62(4):1-9.
5. Manchola-González JD, Bagur-Calafat C, Girabent-Farrés M, Serra-Grima JR, Pérez RA, Garnacho-Castaño MV, et al. Effects of a home-exercise programme in childhood survivors of acute lymphoblastic leukaemia on physical fitness and physical functioning: results of a randomised clinical trial. Supportive Care in Cancer. 2020; 28(7):3171-3178.

6. Naidu D, Borza C, Kobitowich T, Mrazik M. Sideline Concussion Assessment: The King-Devick Test in Canadian Professional Football. Journal of Neurotrauma. 2018 Oct 1; 35(19):2283-2286.

7. Mehta P, McAuley DF, Brown M, Sanchez E, Tattersall RS, Manson JJ, et al. COVID-19: consider cytokine storm syndromes and immunosuppression. Lancet. 2020; 395(10229):1033-4.

8. Viano DC, Withnall C, Halstead D. Correction to: Impact Performance of Modern Football Helmets. Annals of Biomedical Engineering. 2018; 46(1):208-210. 